\title{
New boletoid fungi in the genus Leccinum from Fennoscandia
}

\author{
MAURI KORHONEN
}

\begin{abstract}
Korhonen, M. 1995: New boletoid fungi in the genus Leccinum from Fennoscandia. Karstenia 35:53-66. Helsinki. ISSN 0453-3402

Three new species in the genus Leccinum are described, viz. L. populinum M. Korhonen, L. cerinum M.Korhonen and L. palustre M.Korhonen. Their morphological characters, ecology and distribution in Fennoscandia are discussed. In addition, L. quercinum (Pilàt) E.E.Green \& Watl., L. aurantiacum (Bull.) Gay, L. versipelle (Fr.) Snell, and L. holopus (Rostk.) Watl. are redescribed with more exact characters, to facilitate comparison with the new species.
\end{abstract}

Key words: Boletes, Fennoscandia, Leccinum, taxonomy

Mauri Korhonen, Botanical Museum (Mycology), P.O. Box 47, FIN-00014 University of Helsinki, Finland

\section{Introduction}

Although species of the genus Leccinum Gray (Basidiomycotina: Boletales) are relatively well known in Europe, there remain some undescribed and poorly known species. Our knowledge of the members of Leccinum has gradually increased in recent decades. For example, in British Fungus Flora, Watling (1970) recognizes 13 species. For the whole of Europe, Engel (1983) reports about 27 species, and in the Nordic countries (Kallio 1976, Persson 1992) at least 15 species are known. Many new taxa have recently been published by the French mycologists G. Lannoy and A. Estades (1991a, 1991b, 1993, 1994) and today about 50 taxa (species, subspecies etc.) are recognized in Western Europe alone (Lannoy \& Estades 1994). A new monograph on European Leccinum is soon to be published by Lannoy \& Estades. There are at least twice as many taxa of Leccinum in continental North America as in Europe (Smith \& Thiers 1971, Engel 1983).

This paper adds three new Leccinum species to the flora of Europe. Like most Leccinum species, all the new species, Leccinum populinum, L. cerinum and L. palustre, are mild, highly edible fungi.

\section{Material and methods}

The bolete specimens in herbaria are frequently young, immature fruit bodies, listed without any information on colours and colour changes in the fresh material. Most of the material for this study was collected by myself, during about 10 years, mainly in Finland but also in Sweden and Norway. All the material, at least 3000 collections, is deposited in Helsinki $(\mathrm{H})$. Many of the specimens were photographed at the original site in the field, with an Arca Swiss studio camera on a tripod. The colour film was Kodak Ektachrome 100 professional (EPN 120) rollfilm size, square $6 \times 9 \mathrm{~cm}$.

The microscopical study of specimens was conducted with a Leitz Dialux microscope equipped with a Pl Apo Oel 100/1.32 oil immersion lens. Spores, basidia, cystidia, pileipelles were drawn with a Leitz drawing tube at a magnification of 2000 . All measurements are based on the drawings. Measures are correct down to $1 / 4 \mu \mathrm{m}$, because in measuring spores half a micrometre is never exact enough. All the preparations were mounted in pure water without use of any softening or colour medium. This allowed observation of the natural colour of the structures. Most structures were studied from dry material, some from fresh specimens.

Because a fruit body produces spores continuously, at any given time most of the spores are immature. Care must be taken in choosing mature spores for size measuring. In this work I used absolutely mature spores. Mature 

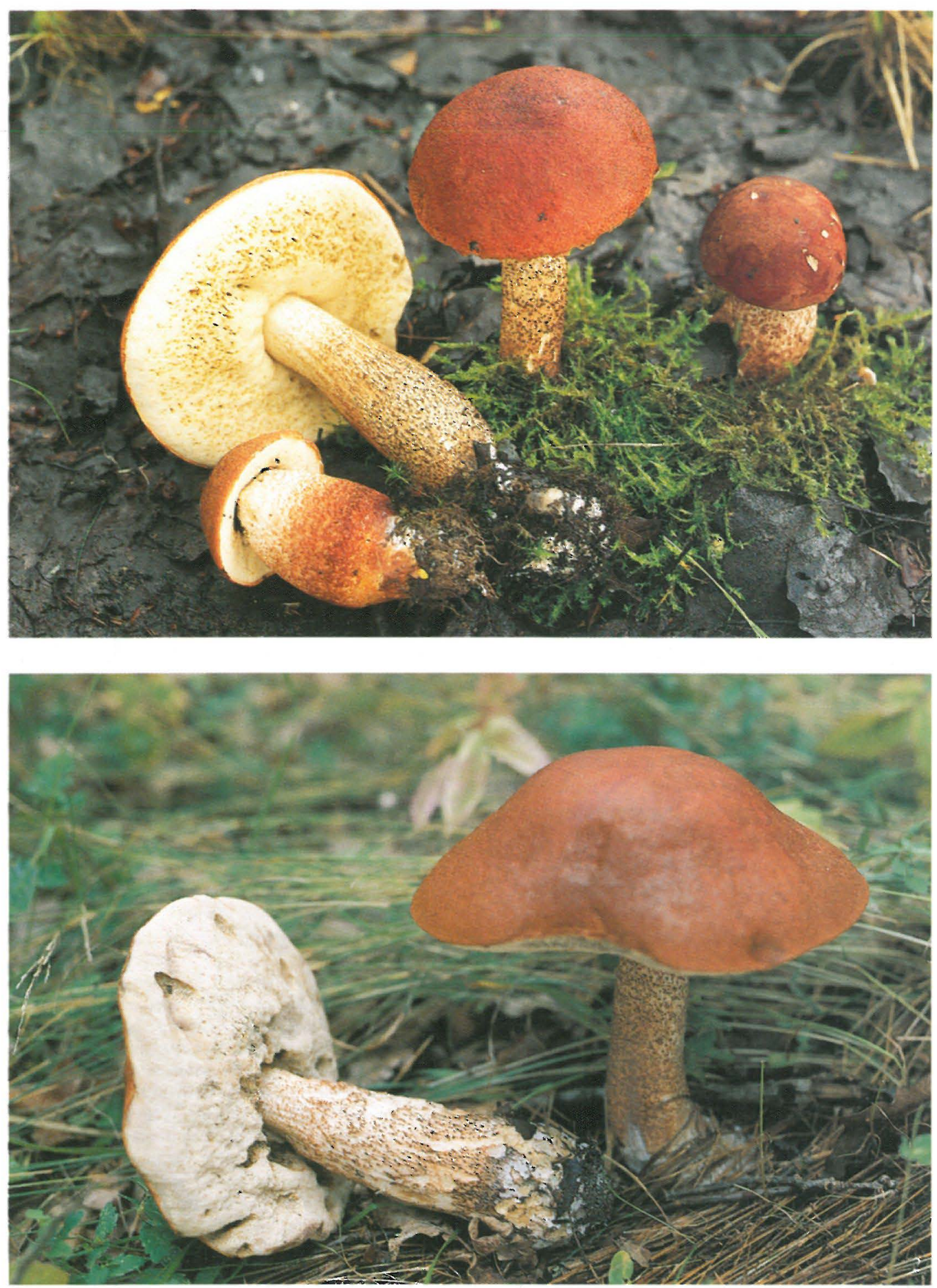

Figs. 1-2. - 1: Leccinum populinum (holotype). Photo 18. IX. 1994 Mauri Korhonen. - 2: Leccinum quercinum (Korhonen 11092, H). Photo 31. VIII. 1992 Mauri Korhonen. 


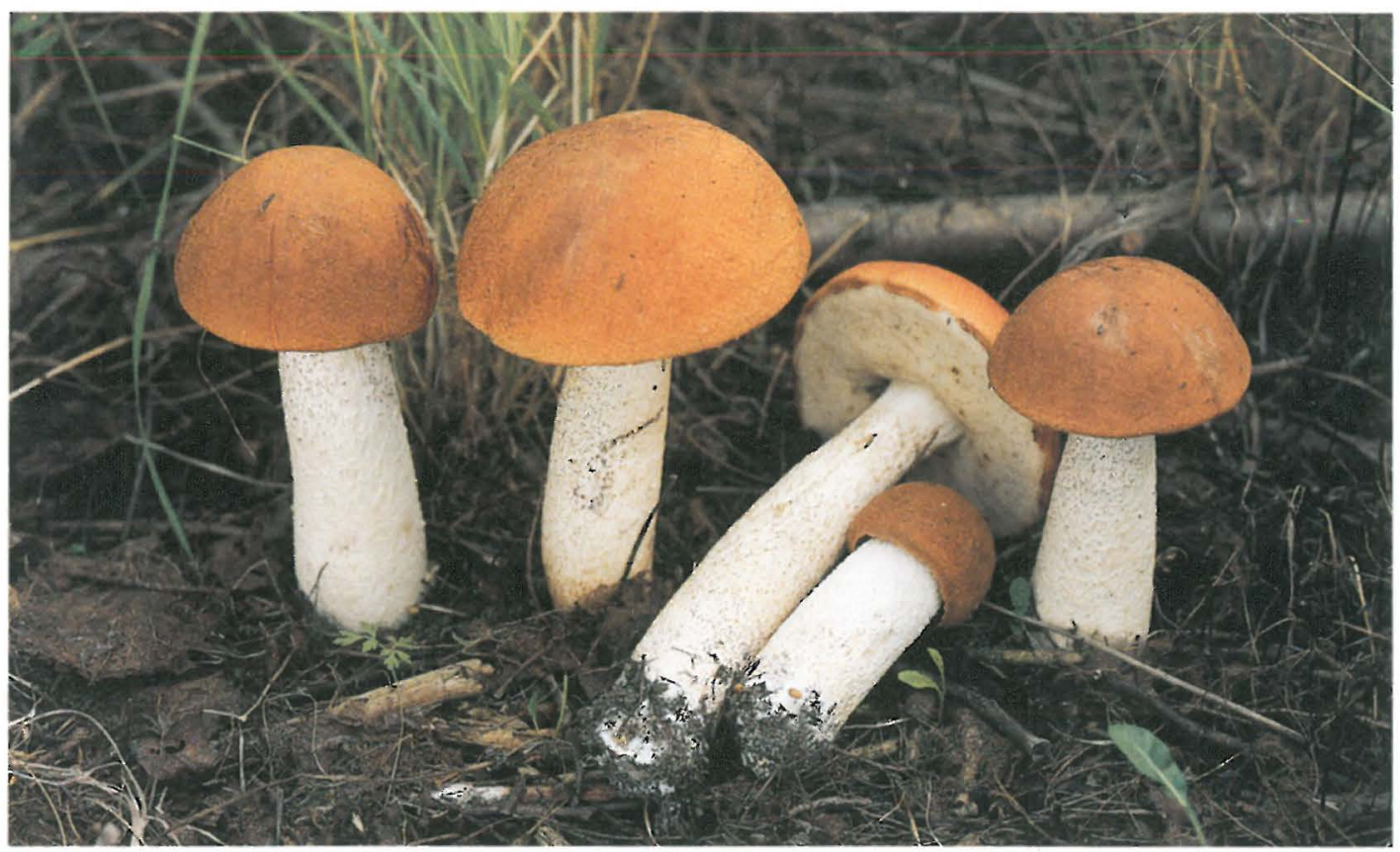

Fig. 3. Leccinum aurantiacum (Korhonen 9807, H). Photo 4. IX. 1990 Mauri Korhonen.

Leccinum spores can be recognized by their larger size, more intense colour and thicker wall.

In many cases there are abundant mature spores, especially on the surface of the pileipellis. On the surface of the stipe there are caulobasidia, and also spores, from the top to the base, but the stipe surface produces only miniature spores, and even the basidia are mostly smaller than those on the tubes.

The length to width ratio was measured for individual spores, and the mean spore volume was calculated according to the formula of an ellipsoid: $4 / 3 \cdot a \cdot a \cdot b(a=$ the radius of the transverse axis; $b=$ the radius of the longitudinal axes; Breitenbach \& Kränzlin 1991). The spore volume was based on the material cited in Figs. 6, 10 and 14. The colour chart system of Kornerup \& Wanscher (1961) was used in the descriptions of species.

Leccinum populinum M.Korhonen, sp. nova - Figs. 1, 4a-d, 6

Sicut Leccinum aurantiacum sed pileus lateritiobrunneus et etiam stipes squamulis ab ineunte lateritio-brunneis instructus; sporis majoribus $(15-21.5 \times 4.5-5.5 \mu \mathrm{m}$, volumen mediocriter $236 \mu^{3}$ ). Una cum Populo vel Tilia crescens.

Type: Finland. Uusimaa: Vantaa, Veromies, field reverted to forest, with Populus tremula, 12.IX.1994 M.Korhonen $11850(\mathrm{H}$, holotype).
Pileus $10-20(-28) \mathrm{cm}$ wide, convex, context thick and firm, young pileus semiglobose, colour dark red-brown. Pileipellis of mature pileus brown red, red brown or dark red-brown $(8 \mathrm{C} 8,8 \mathrm{E} 8,9 \mathrm{D} 8$, 9D9, 9E9; Kornerup \& Wanscher). Surface matt, fine fibrous, covered with very small dark brown scales. Pileipellis slightly overhanging at tubes margin. Context pale grey, tinged with white, when cut turning first greyish rose then slowly bluish red to dark grey. Taste mild, odour pleasant but not strong. Stipe $15-25 \mathrm{~cm}$ long, $2-5 \mathrm{~cm}$ thick, equal or often central part slightly swollen, sometimes tapering towards base. Surface white to greyish yellow with white nuance, fibrous, scales on top small and white, farther down larger and dark redbrown (8D8-8F8). Colour of context as in the pileus, but when cut tinged with bright blue in places. Basal mycelium white. Tubes $2-3 \mathrm{~cm}$ long, small and dense, creamy grey, turning ochre grey at section surface. Colour of young pores light yellow (4A2), old ones slightly more yellow (4A4). Spores $15.25-21.5(-25) \times 4.25-5.5 \mu \mathrm{m}$, long and clearly more cylindrical than those in related species, length/breadth ratio $3.0-4.2$, average 3.6 , volume average $236 \mu^{3}$. Basidia $8-9 \times 23-25 \mu \mathrm{m}$. Caulobasidia are present all over the stipe, from top to base. Pleurocystidia $8-14 \times 30-48 \mu \mathrm{m}$, 

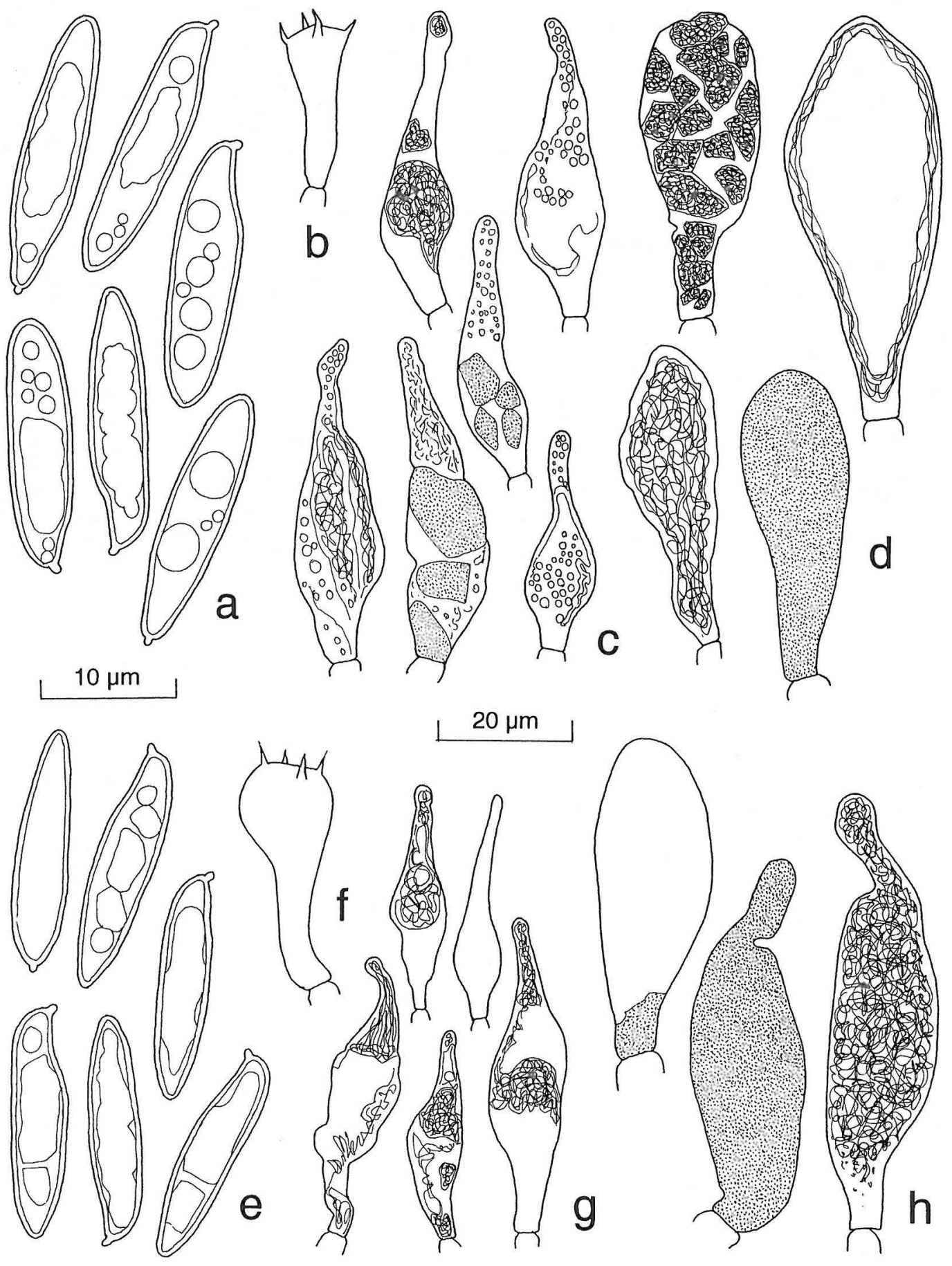

Fig. 4a-d. Leccinum populinum (holotype). - a) spores, b) basidia, c) pleurocystidia, d) caulocystidia. - e-h. $L$. quercinum (Korhonen 11094, H). - e) spores, f) basidia, g) pleurocystidia, h) caulocystidia. Scale of spores $\times 2000$; other elements $\times 1000$. 

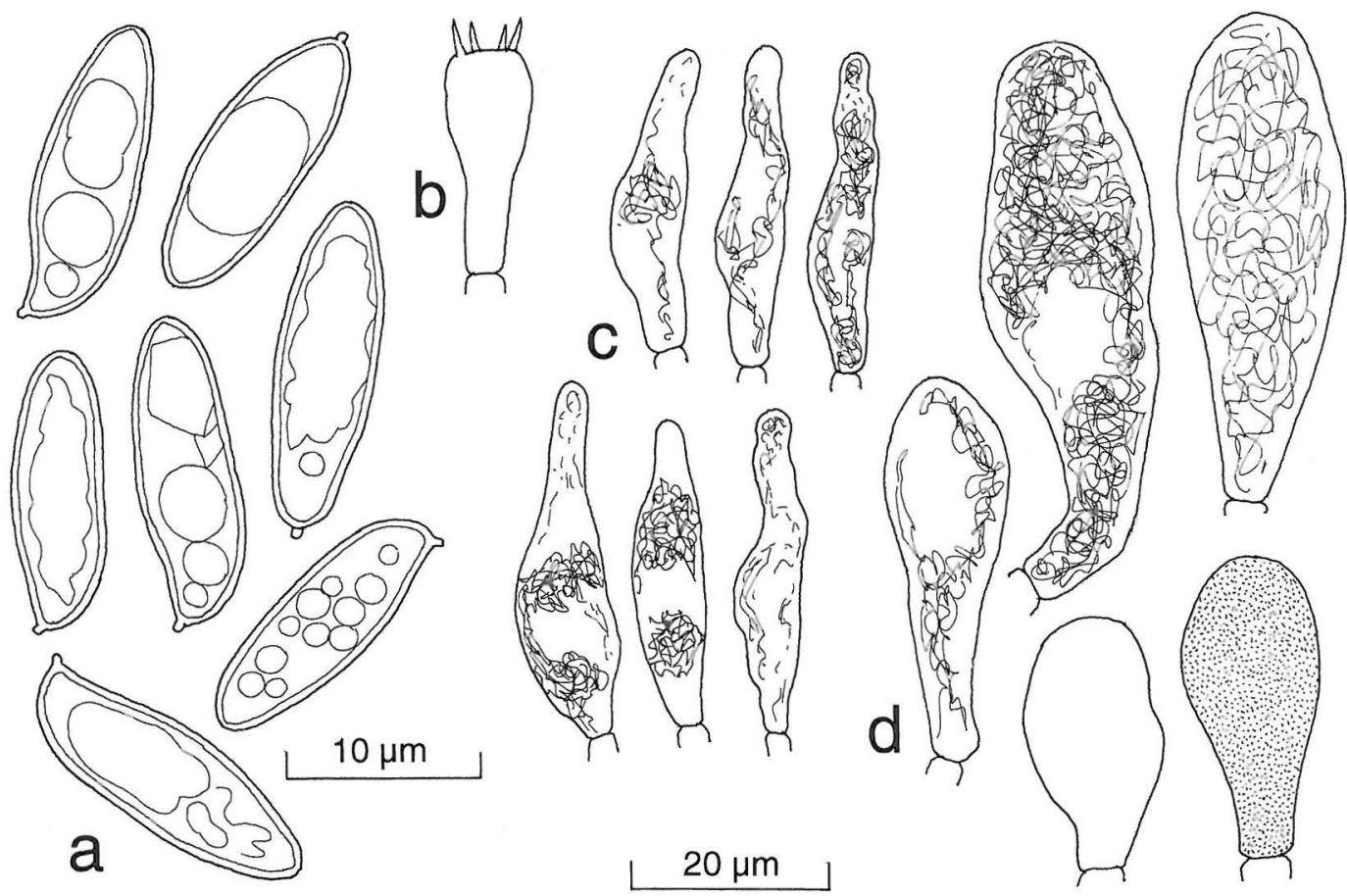

Fig. 5. Leccinum aurantiacum (Korhonen 11079, H). - a) spores, b) basidia, c) pleurocystidia, d) caulocystidia. Scale of spores $\times 2000$; other elements $\times 1000$.

lageniform, more or less encrusted, granulate or with larger particles. Caulocystidia 12-13 × 25$69 \mu \mathrm{m}$, clavate, encrusted, brown, lactiferous-like pale brown or partly hyaline. End cells of pileipellis 8-20 $\times 40-115 \mu \mathrm{m}$, context pale brown, lactiferouslike, some with heavily encrusted dark brown hyphae, a few hyphae hyaline and gelatinous.

Distribution and ecology. Leccinum populinum occurs in Finland in the southern part of the country, at least up to the provinces Keski-Pohjanmaa, Pohjois-Savo and Pohjois-Karjala. Its true northern limit is still unknown. On the south coast of Finland it is fairly common in more fertile forests. It is usually associated with Populus tremula and sometimes with Tilia, but also with the planted trees in parks and urban areas.

In Sweden it was collected two or three times in Dalsland, Hoverud, in 1990 during the Nordic Mycological Congress (by Jan-Olof Tedebrandt and Olle Persson). During the Elias Fries Symposium in 1994 it was on the table in the fungus exhibition in Uppsala. Probably it is by no means rare in southern Sweden.

\section{Representative specimens examined}

Finland. Varsinais-Suomi: Tammisaari, Bromarv, Sol- böle, 1992 Korhonen $11084(\mathrm{H}), 1993$ Korhonen 11580 (H). Uusimaa: Kirkkonummi, Ursbyberget, 1990 Korhonen $9797(\mathrm{H})$; Lapinjärvi, in Populus tremula plantation, 1992 Korhonen 11247 (H). Sweden. Dalsland: Håverud, Hovgằd, 1990 Korhonen 9881, $9896(\mathrm{H})$.

Leccinum quercinum (Pilát) E.E.Green \& Watl. - Figs. 2, 4e-h, 6

Pileus 6-15 $\mathrm{cm}$ wide, rusty brown, red brown or dark brick-red (8D6), young cap globose, then convex, context thick and firm, surface first matt, dark, older fibrous, with small scales, pileipellis slightly overhanging the margin. Context white, cream white, when cut turning wine red in pileus, in stipe greyish blue to red, at base often tinged with blue green, taste mild, odour pleasant. Stipe 11$18 \mathrm{~cm}$ long, $2-3 \mathrm{~cm}$ thick, equal or tapering towards base, often very thick at top. Surface brown, tinged with white, fibrous, scales red brown to dark sepia brown. Basal mycelium white. Tubes dirty white, yellowish, pores white, older yellowish. Spores 13$18 \times 3.75-4.75 \mu \mathrm{m}$, length/breadth ratio 3.0-4.2, average 3.6, volume average $157 \mu \mathrm{m}^{3}$. Basidia $13 \times$ $32 \mu \mathrm{m}$. Caulobasidia present all over stipe. Pleurocystidia 6-11 × 25-46 $\mu \mathrm{m}$, hyaline to 


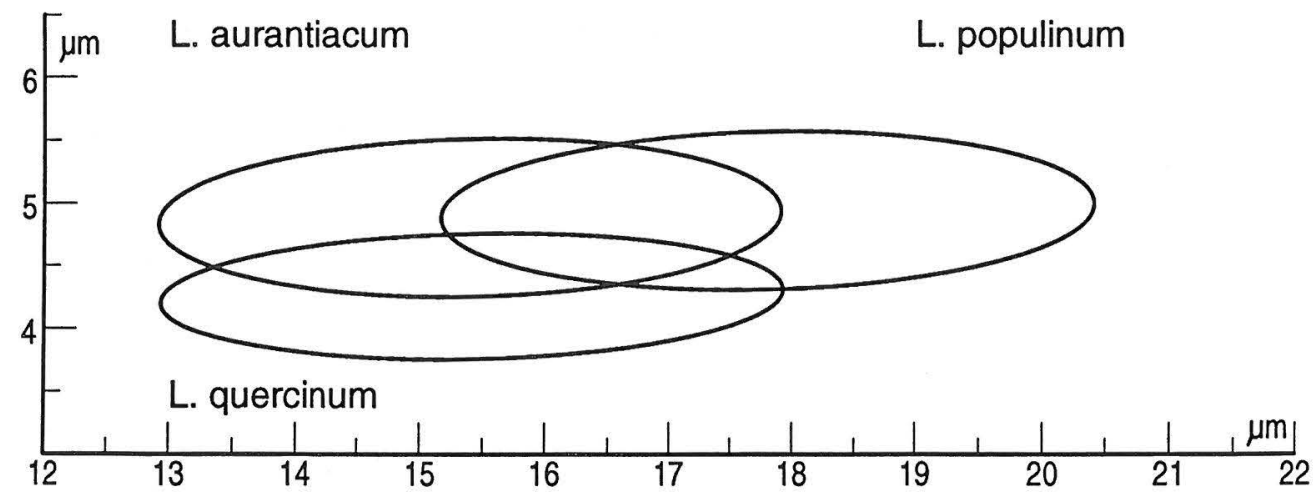

Fig. 6. Diagram showing the spore size differences of Leccinum populinum, L. quercinum and L. aurantiacum. The lines are drawn on the basis of scatter diagrams and embrace ca. $95 \%$ of the spores measured for each species (L. populinum, 726 spores, 18 specimens; L. quercinum, 543 spores, 7 specimens; L. aurantiacum, 596 spores, 20 specimens); $\mathrm{x}$ axis, length of spores; $y$ axis, width of spores.

encrusted, lageniform. Caulocystidia 10-17 ×40$68 \mu \mathrm{m}$, clavate-mucronate to lageniform. End cells of pileipellis $4-10 \times 30-48 \mu \mathrm{m}$, context, with gelatinous hyaline hyphae, pale brown lactiferouslike hyphae or dark brown encrusted hyphae.

Distribution and ecology. The distribution in Finland is concentrated on the SW coast of the country, where the species is nevertheless relatively rare, mainly limited to the hemiboreal zone with native distribution of Quercus robur. Very rarely it is found outside the hemiboreal zone up to the province Etelä-Häme, where there are single planted Quercus trees in parks. Associated with Quercus robur, more rarely associated with Fagus (in other countries, not Finland).

Common in southern Sweden; in Norway in the south and to Aust-Agder in the west (Persson 1992).

\section{Representative specimens examined}

Finland. Varsinais-Suomi: Tammisaari, Bromarv, Solböle, Korsudd, 1978 Korhonen \& Tuomikoski 2261 (H), 1990 Korhonen 9997 (H), 1992 Korhonen $11094(\mathrm{H})$.

\section{Leccinum aurantiacum (Bull.) Gray -} Figs. 3, 5a-d, 6

Pileus 8-25 cm wide, convex, context thick and firm, orange to brown orange or brown red (7B8, $7 \mathrm{C} 8,8 \mathrm{C} 8$ ), surface matt, fine fibrous, small scales, pileipellis slightly overhanging the margin. Context cream white, turning reddish blue at the section surface, but not very dark. Taste mild and odour pleasant. Stipe 10-25 cm long, 2-5 cm thick, equal or slightly swollen toward base. Surface fibrous and scaly, colour white, young scales white, old red brown, generally not dark. When cut turning bluish red, at the base blue areas here and there. Basal mycelium white. Tubes small and dense, $2-3 \mathrm{~cm}$ long, white, at section surface turning light reddish. Pores cream white (5A4), on bruising pale reddish blue. Spores 13-18(-22) $\times 4.25-5.5(-7) \mu \mathrm{m}$, length/breadth ratio 2.8-3.6, average 3.2, volume average $209 \mu \mathrm{m}^{3}$. Basidia 8$9 \times 21-23 \mu \mathrm{m}$. Caulobasidia are present all over stipe. Pleurocystidia 7-10 × 30-36 $\mu \mathrm{m}$, fusoidventricose. Caulocystidia 9-20 × 22-56 $\mu \mathrm{m}$, clavate. End cells of pileipellis 7-24 × 40$150 \mu \mathrm{m}$, most hyaline or pale brown granulate, a few slightly encrusted.

Distribution and ecology. Leccinum aurantiacum is widely distributed in the Nordic countries, occurring everywhere except in high mountain areas and the northern part of Norway. In Finland it is common in the south, rarer the north. It has been found in the northernmost province Inarin Lappi. In Norway the distribution extends to the province Nordland.

L. aurantiacum is associated with Populus tremula, growing in more fertile forests, and with single trees in parks and along roadsides.

\section{Representative specimens examined}

Finland. Uusimaa: Tammisaari, Prästviken, Prästängarna, 1992 Korhonen 11079 (H); Kirkkonummi, Ursbyberget, 1994 Korhonen 11857 (H); Vantaa, Veromies, 1994 

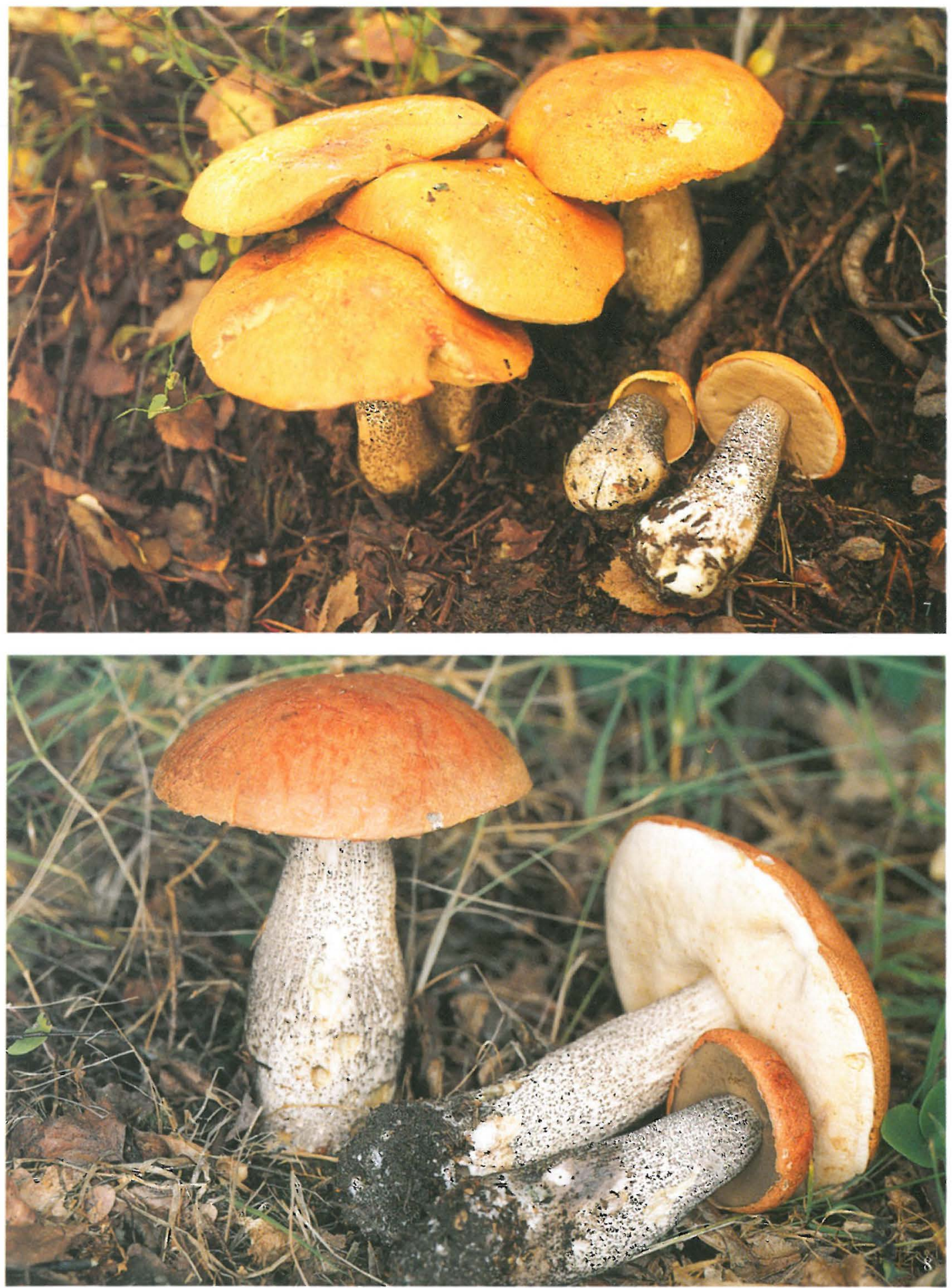

Figs. 7-8. - 7: Leccinum cerinum (holotype). Photo 2. X. 1994 Mauri Korhonen. - 8: Leccinum versipelle (Korhonen 8414, H). Photo 30. VIII. 1988 Mauri Korhonen. 

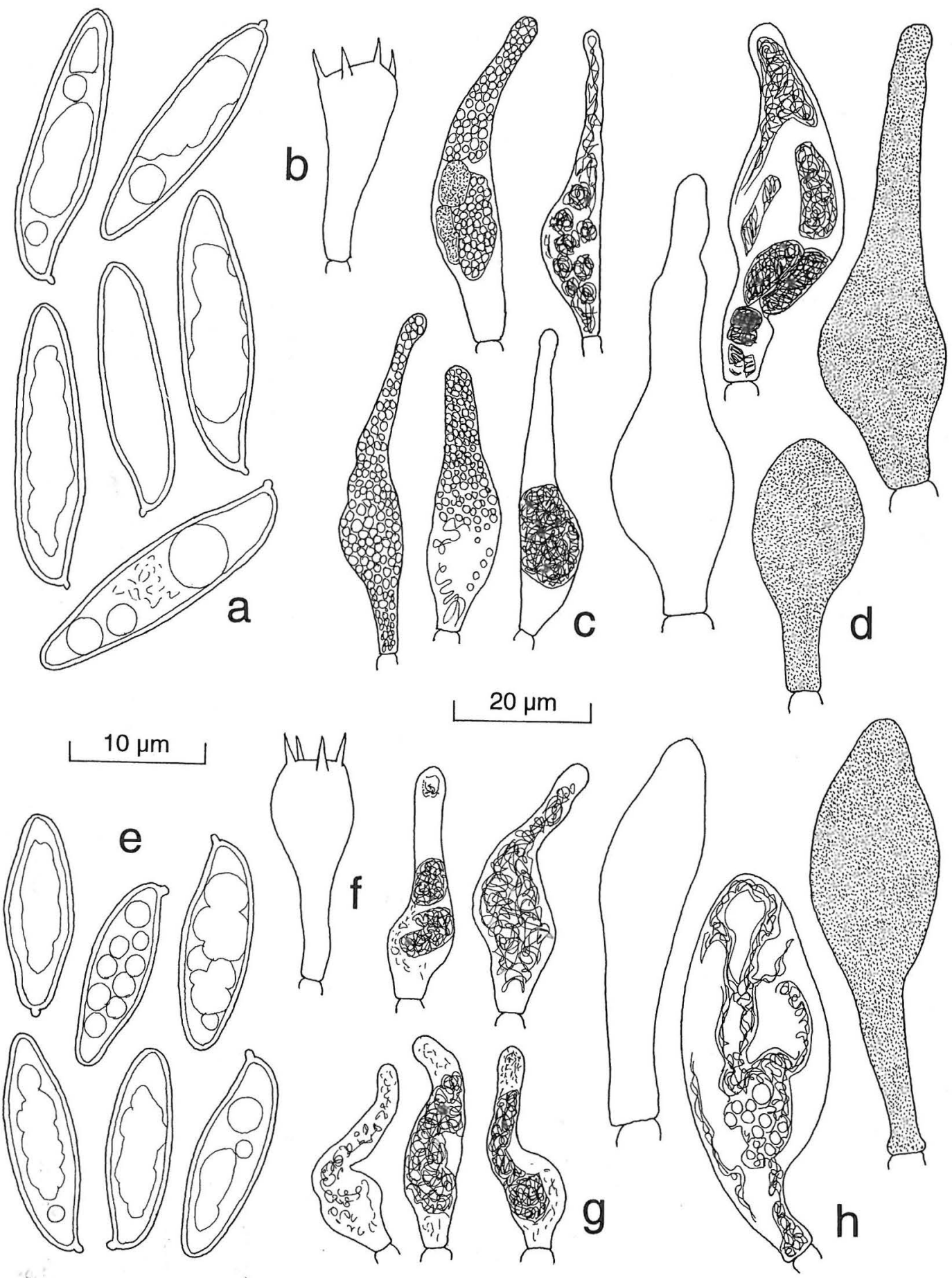

Fig. 9 a-d. Leccinum cerinum (holotype). - a) spores, b) basidia, c) pleurocystidia, d) caulocystidia. - e-h. L. versipelle (Korhonen 11730, H). - e) spores, f) basidia, g) pleurocystidia, h) caulocystidia. Scale of spores $\times 2000$; other elements $\times 1000$. 


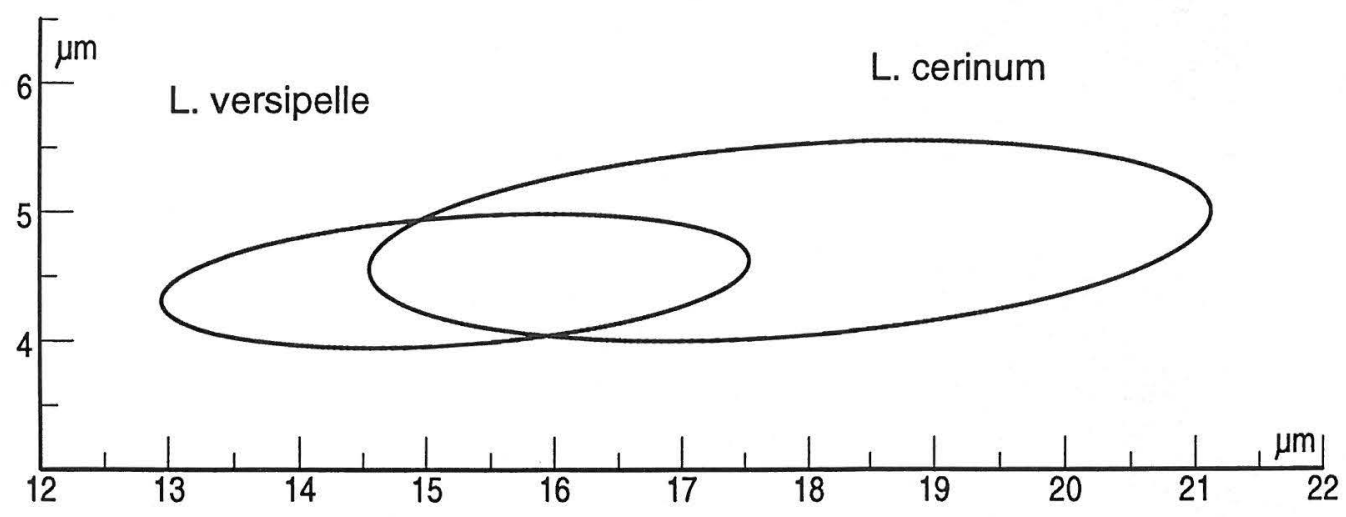

Fig. 10. Diagram showing the spore size differences of Leccinum cerinum and $L$. versipelle. The lines are drawn on the basis of scatter diagrams and embrace ca. 95\% of the spores measured for each species (L. cerinum, 1544 spores, 29 specimens; L. versipelle, 1077 spores, 20 specimens); x axis, length of spores; $y$ axis, width of spores.

Korhonen 11884 (H); Lapinjärvi, Populus tremula plantation, 1992 Korhonen 11248 (H). Etelä-Pohjanmaa: Ylistaro, Vittinki, 1988 Kytövuori 88269 (H). KeskiPohjanmaa: Pyhäjärvi, Maanselänkangas, 1992 Korhonen $11059(\mathrm{H})$.

Leccinum cerinum M.Korhonen, sp. nova - Figs. 7, 9a-d, 10

Sicut Leccinum versipelle sed pileus flaventior, stipes squamulis lateritio-brunneis instructus, stratum tubulorum basi abrupte sinuatum et sporae majores (14.5-21 ×4-6 $\mu$ m, volumen mediocriter $\left.211 \mu^{3}\right)$. Una cum Betula crescens.

Type: Finland. Uusimaa: Vantaa, Veromies, field reverted to forest, associated with Betula, 2.X.1994 M.Korhonen 11969 (H, holotype).

Pileus 11-21(-27) cm wide, convex, open very early, context thick and firm. Pileipellis greyish yellow, brown yellow, grey orange, brown orange, yellow brown tinged with red or light red to yellow (5B5, 5B6, 6D4, 6D5). Surface matt, fine fibrous, with small scales, pileipellis slightly overhanging the margin. Context white, when cut very slowly turning reddish, then bluish to blue greenish, in a few places bright blue, especially at stem base. Taste mild and odour pleasant, not strong. Stipe 7$21 \mathrm{~cm}$ long, 2.5-6 (at base even 8) cm thick, generally equal or tapering toward base, surface colour pale, tinged with reddish grey, scales brown to pale grey, greyish beige brown, ochre brown or umbra brown, sometimes very dark. Basal mycelium white. Tubes $1.5-3.5 \mathrm{~cm}$ long, small and dense, colour yellow grey (5B3), pores when young pale greyish yellow, later yellow grey (5B6). Spores 14.5-21(-29.5) ×4-5.75 (-6.5) $\mu \mathrm{m}$, length/breadth ratio 3.2-4.4, average 3.7 , volume average $211 \mu \mathrm{m}^{3}$. Basidia 9-12×25-30 cm. Caulobasidia are present all over stipe. Pleurocystidia 7-10 × 31-60 $\mu \mathrm{m}$, lageniform. Caulocystidia 11-16 × 45-85 $\mu \mathrm{m}$, clavate, lageniform or broadly fusoid-ventricose. End cells of pileipellis 5-13 $525-70 \mu \mathrm{m}$, hyphae hyaline or pale brown to brown, granulate.

Distribution and ecology. Leccinum cerinum is widely distributed in Fennoscandia. It is very common from the south to extreme north and even occurs in high mountain areas.

It is associated with all Betula species, including the shrub or dwarf shrub Bétula nana in treeless mountain regions. In Finland it seems to be everywhere at least as common as $L$. versipelle.

Like $L$. versipelle it is much consumed for food, though neither species should be eaten in raw condition to avoid digestive problems.

\section{Representative specimens examined}

Finland. Varsinais-Suomi: Tammisaari, Bromarv, Solböle, Korsudd, 1994 Korhonen 11984 (H). Uusimaa: Tammisaari, Prästvik, Prästängarna, 1994 Korhonen 11992 (H); Espoo, Mankkaa, 1994 Korhonen 12000 (H). Enontekiön Lappi: Kilpisjärvi, Saana, 1991 Korhonen $10366(\mathrm{H})$. Norway. SørNordland: Rana, Umbukta, 1994 Korhonen $11802(\mathrm{H})$; Rana, Saltdal, Semska-Stødi, 1994 Korhonen 11800 (H). Troms: Storfjord, Skibotndalen, Helligskog, 1992 Korhonen $10888(\mathrm{H})$; Storfjord, Signaldalen, Paras, 1994 Korhonen 11752 (H). Sweden. Uppland: Östuna, Brobybacka, 1994 Korhonen $11845(\mathrm{H})$. Medelpad: Ange, Julåsen, 1993 Korhonen $11526(\mathrm{H})$; Ånge, Värsjötjärna, 1994 Korhonen 

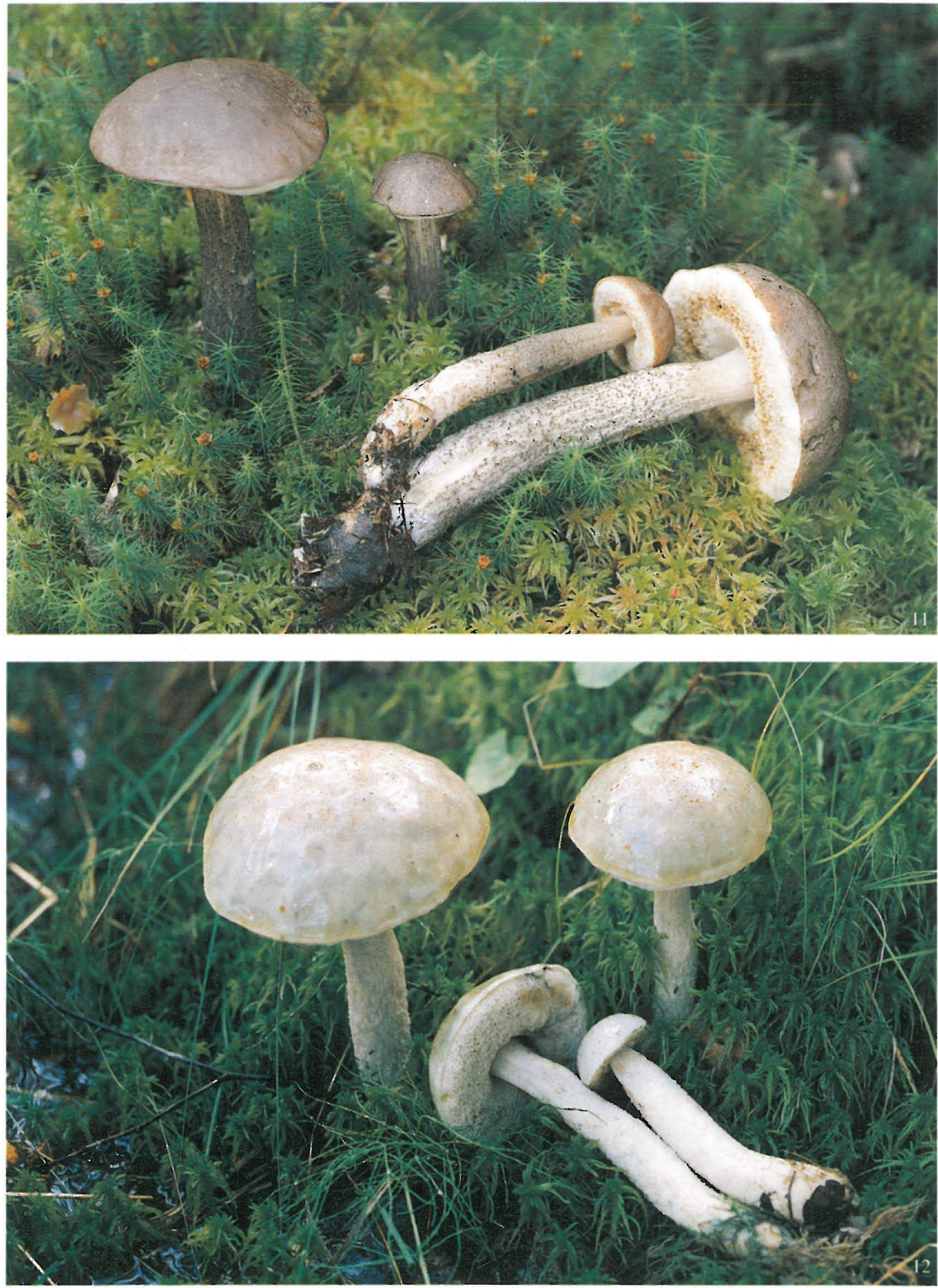

Figs. 11-12. - 11: Leccinum palustre (Korhonen 10966, H). Photo 23. VIII. 1992 Mauri Korhonen. - 12: Leccinum holopus (Korhonen 11121, H). Photo 4. IX. 1992 Mauri Korhonen. 
$11830(\mathrm{H})$. Åsele Lappmark: Vilhelmina, Saxnäs, Stikken, 1994 Korhonen 11814 (H). Torne Lappmark: Abisko, 1994 Korhonen $11794(\mathrm{H})$.

\section{Leccinum versipelle (Fr.) Snell - Figs. 8, 9e-h, 10}

Pileus 10-25(-30) cm wide, convex, context thick and firm, colour ochre brown, brownish yellow, yellow red or orange red, surface matt, fine fibrous, small scales, pileipellis slightly overhanging the margin. Context white tinged with grey, waterish white, turning slowly first grey-reddish violet finally black grey. Taste mild and odour pleasent. Stipe $15-25 \mathrm{~cm}$ long, $1.5-3 \mathrm{~cm}$ thick, equal or sligthly swollen toward base, surface colour white to pale greyish white, scales first pale grey, then grey and later black. Basal mycelium white. Tubes 2-3 cm long, adnexed, small and dense, young pores dark grey, then greyish white ochre to yellowish grey. Spores $13-1(-18.5) \times 4-5(-5.25)$ $\mu \mathrm{m}$, length/breadth ratio $2.7-3.8$, average 3.1 , volume average $165 \mu^{3}$. Basidia 9-12 × 30-36 $\mu \mathrm{m}$. Caulobasidia are present all over stipe. Pleurocystidia 6-11 × 26-38 $\mu \mathrm{m}$, lageniform. Caulocystidia $11-24 \times 32-70 \mu \mathrm{m}$, clavate, lageniform or broadly fusoid-ventricose, hyaline, partly encrusted or pale brown, lactiferous-like.

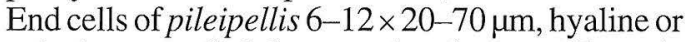
pale brown, slightly granulated or totally pale brown, lactiferous-like.

Distribution and ecology. Leccinum versipelle is widely distributed in Fennoscandia, ocurring in all vegetation zones, even in the far north. It is associated with Betula, and above the timberline with Betula nana, but there it occurs only occasionally, and often deformed, like most fungi in that zone.

In Finland $L$. versipelle is a much sought after species and also a commercial fungus. Eaten raw it can cause gastric disorder.

\section{Representative specimens examined}

Finland. Varsinais-Suomi: Tammisaari, Bromarv, $5 \mathrm{~km} \mathrm{~S}$ from village, 1994 Korhonen $11950(\mathrm{H})$; Uusimaa: Tammisaari, Prästviken, Prästängarna, 1990 Korhonen 9765 (H); Vantaa, Veromies, 1993 Korhonen 11576 (H). Perä-Pohjanmaa: Rovaniemi rural parish, Vanttauskoski, Isokivalo, 1988 Korhonen $8575(\mathrm{H})$.

Leccinum palustre M.Korhonen, sp. nova - Figs. 11, 13a-j, 14

Sincut Leccinum holopus sed pileus fusco-griseus et stipes squamulis griseis vel atro-griseis instructus, stratum tubulorum basi sinuatum, senectute non tumescens; sporae majores (16-22x $\left.6-7 \mu \mathrm{m}^{3}\right)$. Una cum Betula crescens.

Type: Finland. Uusimaa: Vantaa, Veromies, field reverted to forest, with Betula pubescens, 7.IX.1992 M.Korhonen 11145 ( $\mathrm{H}$, holotype).

Pileus 6-11 cm wide, even old fruit bodies high convex, context firm, pileipellis colourfull even when young, pale brown grey to brown, tendency of grey colour to dominate and increase with age, turning greenish only slightly, surface of a dry cap matt, shining silver, white grey, old waterish grey, pileipellis overhang margin minimally. Context greyish white, at section surface turning very pale reddish and then pale waterish blue green, at stipe bright turquoise blue some spots, especially at base. Stipe $10-15 \mathrm{~cm}$ long, 1-2.5 cm thick, equal or somewhat swollen toward base, surface greyish white, pale brown shining, fibrous and scaly, scales first pale brown grey, then grey to dark grey. Basal mycelium white. Tubes $1-2.5 \mathrm{~cm}$ long, emarginate, only slightly plump in shape even when old, grey tinged with red, at section surface turning dirty reddish. Pores small and dense, $16-18 / \mathrm{cm}$. Spores $16-22(-23) \times 6-7.25 \mu \mathrm{m}$, length/breadth ratio $2.4-3.8$, average 2.8 , volume average $408 \mu^{3}$. Basidia 10-12 × 27-37 $\mu \mathrm{m}$, caulobasidia present all over stipe. Pleurocystidia 6-11 × 36-65 $\mu \mathrm{m}$, lageniform. Caulocystidia $12-20 \times 55-83 \mu \mathrm{m}$, lageniform, hyaline, but also some dark hyphae similar to those on pileipellis occur in scales on stipe surface. Pileipellis hyphae 5-11 $\mu \mathrm{m}$ wide and 40-100 $\mu \mathrm{m}$ long, both hyaline and heavily encrusted dark brown under the microscope clearly clustered.

Distribution and ecology. Leccinum palustre is widely distributed in Fennoscandia, extending even to the northernmost parts of Finland and Norway. In Finland it is a common but not abundant species and occurs especially among Sphagnum and Polytrichum commune in bogs and other wet depressions, associated with Betula. I have also found it in many places in Sweden and Norway. It has commonly been confused with L. holopus.

Representative specimens examined

Finland. Varsinais-Suomi: Vihti, Nummela, 1992 Korhonen 11209 (H). Uusimaa: Espoo, Luukkaa, 1992 Korhonen 11325 (H); Espoo, Mankkaa, Mankkaansuo, 1992 Korhonen $11330(\mathrm{H})$; Kirkkonummi, Ursbyberget, 1992 Korhonen 11122 (H); Vantaa, Viinikanmäki, Mottisuo, 1982 Korhonen 4879 (H). Perä-Pohjanmaa: Rovaniemi rural parish, Vanttauskoski, Kaihuanvaara, Kylmäoja, 1992 Korhonen $10974(H)$. Norway. Troms: Storfjord, Signaldalen, Paras, 


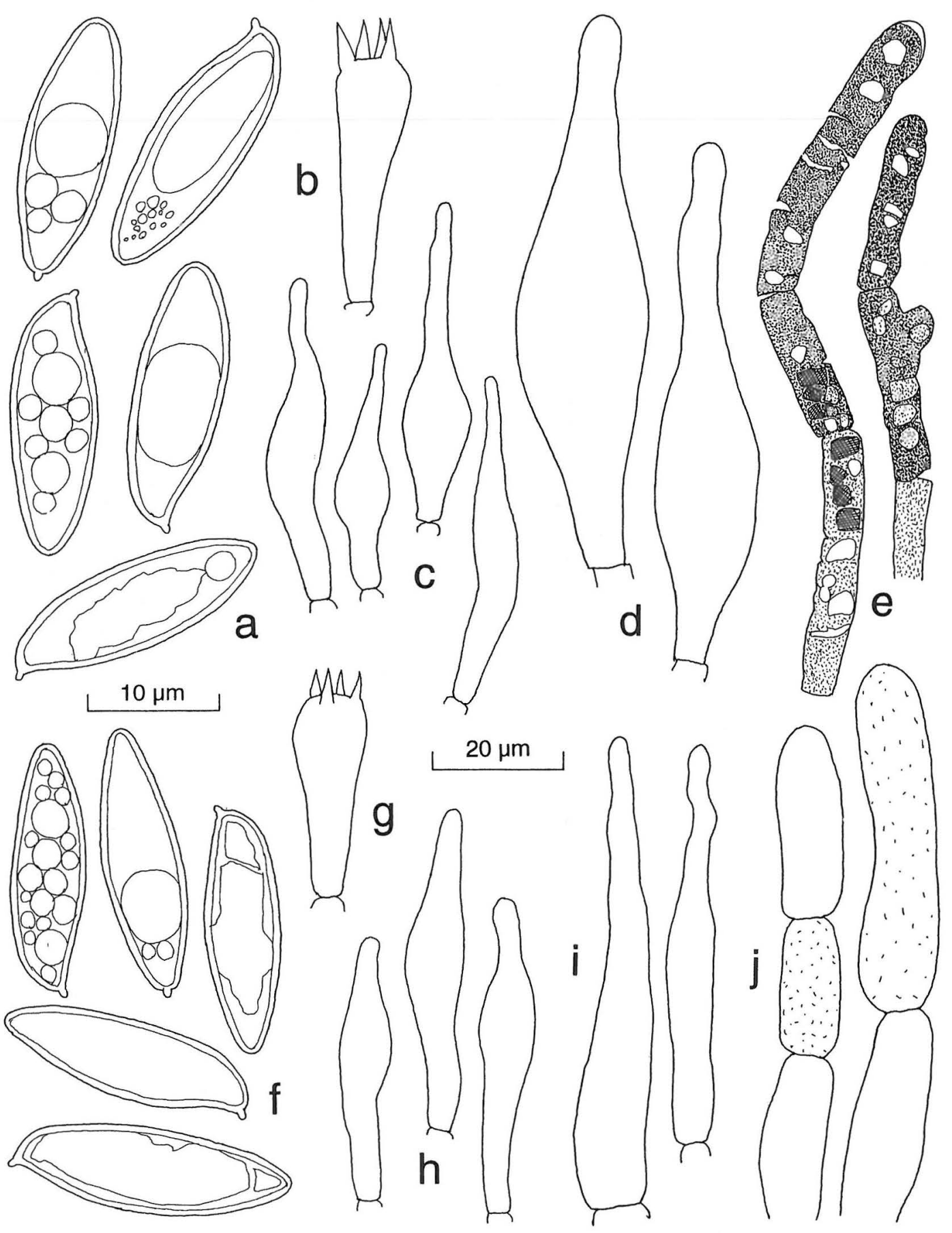

Fig. 13a-j. - a-e. Leccinum palustre (holotype). - a) spores, b) basidia, c) pleurocystidia, d) caulocystidia, e) hyphae of pileipellis. - $\mathrm{f}-\mathrm{j}$. L. holopus (Korhonen 11121, H). — f) spores, g) basidia, h) pleurocystidia, i) caulocystidia, j) hyphae of pileipellis. Scale of spores $\times 2000$; other elements $\times 1000$. 


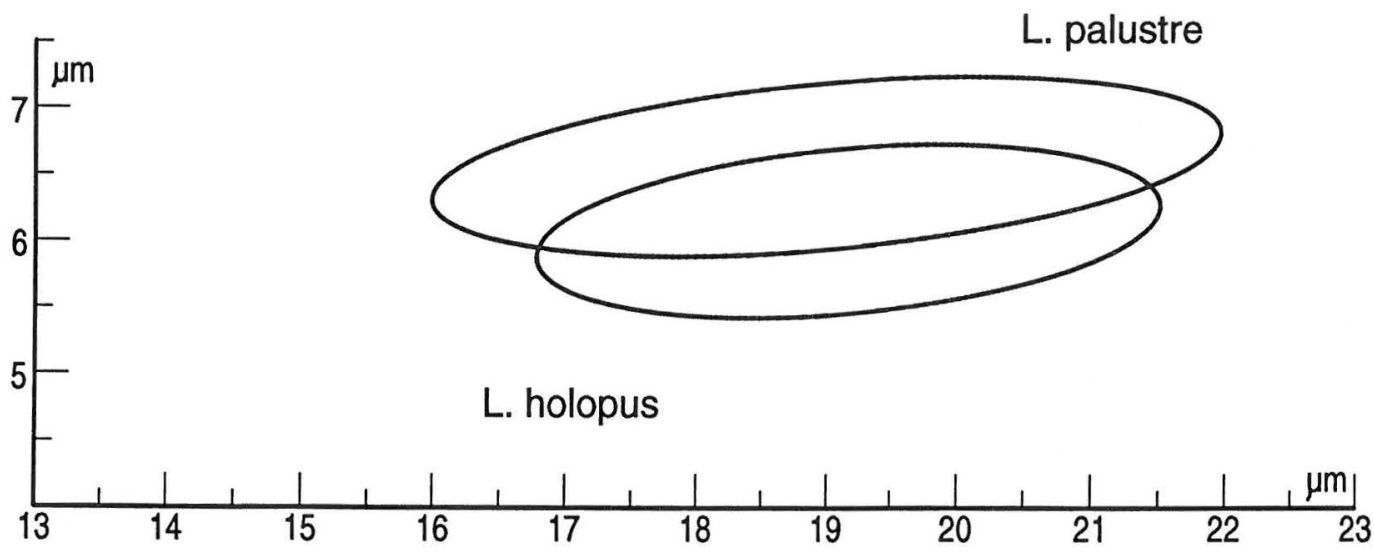

Fig. 14. Diagram showing the spore size differences of Leccinum palustre and L. holopus. The lines are drawn on the basis of scatter diagrams and embrace ca. $95 \%$ of the spores measured for each species (L. palustre, 477 spores, 9 specimens; L. holopus, 284 spores, 6 specimens); $\mathrm{x}$ axis, length of spores; $\mathrm{y}$ axis, width of spores.

1994 Korhonen 11750 (H). Sweden. Uppland: Uppsala, Brunna, Fiby urskog, 7.IX.1994 P. Kytövuori (H). Medelpad: Ånge, Ljungaverk, Höganäs, 1993 Korhonen $11517(\mathrm{H})$.

\section{Leccinum holopus (Rostk.) Watl. - Figs. $12,13 \mathrm{f}-\mathrm{j}, 14$}

Pileus 4-10 cm wide, convex, context relatively thick, soft, pileipellis white, dirty white or yellow greyish white, old fruit bodies turning distinctly greenish, very old pileus totally blue green. Stipe 8$14 \mathrm{~cm}$ long, 1-2 cm thick, equal or nearly so, white, greyish white, surface fibrous and scaly, scales white from young to old, very old pale ochre, basal mycelium white. Tubes 1-2 cm long, emarginate, white tinged with grey and older tinged with red and grey green, at section surface tinged with red and ochre, pores white, small, $0.6 \mathrm{~mm}$ wide. Spores $16.75-21.5 \times 5.5-6.75 \mu \mathrm{m}$, length/breadth ratio 2.6-3.8, average 3.2, volume average $318 \mu \mathrm{m}^{3}$. Basidia 10-12 $\times 25-33 \mu \mathrm{m}$. Pleurocystidia $6-12 \times$ 40-52 $\mu \mathrm{m}$, fusoid-ventricose. Caulocystidia 7-10× 38-72 $\mu \mathrm{m}$, fusoid-ventricose. Pileipellis end cells $8-12 \times 28-87 \mu \mathrm{m}$, pileipellis hyphae mostly hyaline or nearly so, in very old cap numerous darker brown hyphae and planty only $2-5 \mu \mathrm{m}$ wide hyaline hyphae among large hyphae.

Distribution and ecology. Leccinum holopus occurs throughout Fennoscadia. It is common but not a very abundant species, associated with Betula, growing in bogs and other wet depressions often among Sphagnum. It is more common in Finland than in the other Nordic countries because of the predominance of bogs.

\section{Representative specimens examined}

Finland. Uusimaa: Espoo, Luukkaa, 1986, 1992 Korhonen 7237, 11326 (H); Espoo, Mankkaa, Mankkaansuo, 1988 Korhonen 8677 (H); Hanko, Krogars, 1990 Korhonen $10017(\mathrm{H})$; Vantaa, Veromies, 1992 Korhonen $11228(\mathrm{H})$. Perä-Pohjanmaa: Rovaniemi rural parish, Vanttauskoski, Kaihuanvaara, Rantala, 1992 Korhonen 11043 (H).

\section{Discussion}

Leccinum populinum, L. quercinum and $L$. aurantiacum

The species Leccinum populinum, L. quercinum and L. aurantiacum are clearly distinguished from each other by their macroscopical and microscopical characters and in part by their distributions and host trees. L. populinum is more intensively and darker coloured than L. aurantiacum, and the scales of the stipe are red brown even when young, while those of $L$. aurantiacum are totally white. The stipe scales of $L$. quercinum are at first pale, then red brown and finally very dark sepia and toward base partly network-like. The pileus is dark red brown. The pileus of $\mathrm{L}$. aurantiacum is more orange than the pilei of the other species. Most of the pileipellis hyphae of $L$. aurantiacum are broad and hyaline, those of $L$. quercinum very dark brown intercellular encrusted. $L$. populinum has abundant brown hyphae, lactiferous-like.

Leccinum quercinum is a southern species in Scandinavia, associated with Quercus, while $L$. populinum occurs much more to the north, associated with Populus tremula. L. aurantiacum, which has the widest distribution of the three 
species in the Nordic countries, likewise is associated with $P$. tremula.

Leccinum populinum is a distinct and easily distinguished species, though it has been confused until now with both $L$. quercinum and $L$. aurantiacum. In fact, L. quercinum is much rarer in Finland than has been thought. L. populinum has often been misidentified as L. quercinum.

\section{Leccinum cerinum and $L$. versipelle}

The species Leccinum cerinum and $L$. versipelle, both very common throughout Fennoscandia, are macroscopically so similar that their distinctive characters have been overlooked. However, they are easily distinguished on the basis of many diagnostic characters, both macroscopical and microscopical.

The young pileus of $L$. versipelle has dark grey pores, and $L$. cerinum pale cream white. Basic colour of the stipe of $L$. versipelle is white, tinged with grey, and stipe scales are pure grey or grey black. L. cerinum has a more colourful stipe, tinged with red brown, and reddish brown or dark brown scales. Tubes of the mature pileus of $L$. versipelle are adnexed, in $L$. cerinum emarginate. Relative to $L$. versipelle, $L$. cerinum has longer spores with much larger volume, and slimmer and longer pleurocystidia.

\section{Leccinum palustre and L. holopus}

The members of the species pair Leccinum palustre and $L$. holopus can easily be identified even in the field. The colouring is different: young L. palustre is brownish grey, L. holopus whitish or dirty white. The grey colour of $L$. palustre become stronger, but $L$. holopus stays pale, turning only more bluish green. The stipe scales of $L$. palustre are coloured, first pale grey, then dark grey to blackish, while in $L$. palustre they are white and tinged with ochre only on very old stipes. Spore size and volume are much larger in L. palustre than in L. holopus. A big difference is in the hyphae of pileipellis: in $L$. holopus the hyphae are hyaline or almost so, in $L$. palustre there are thick clusters of dark brown, heavily encrusted hyphae.

The name Leccinum niveum (Fr.) Rauschert has sometimes been used for L. holopus (Rostk.) Watl.
(Persson 1992). In my opinion they are separate taxa.

Leccinum olivaceosum Lannoy \& Estades (1994) is another species closely related to $L$. holopus and L. palustre; pilei are pale beige, tinged with light red and grey, quickly turning olive green; tubes are often swollen and stipe scales are pale, tinged with red and brown. L. olivaceosum occurs in Finland, but its distribution and ecology are still poorly known. The identification has been confirmed with the type specimen from France (herb. Lannoy).

Acknowledgements. I thank Prof. Teuvo Ahti for valuable suggestions regarding the manuscript. My thanks are also expressed to Mr. Gilbert Lannoy and Dr. Roy Watling.

\section{References}

Alessio, C. L. 1985: Boletus. Fungi europaei 2. - 712 pp. Biella Giovanni, Saronno.

Breitenbach, J. \& Kränzlin, F. 1991: Fungi of Switzerland. 3. - $361 \mathrm{pp}$. Edition Mykologia, Lucerne.

Engel, H. 1983: Rauhstielröhrlinge. Die Gattung Leccinum in Europa. - 84 pp. Heinz Engel, Coburg.

Kallio, P. 1976: Tatit —Boletaceae. In: Ulvinen, T. (ed.), Suursieniopas: 37-49. - Suomen Sieniseura, Helsinki.

Kornerup, A. \& Wanscher, J. H. 1961: Värien kirja. 260 s., Porvoo, WSOY.

Lannoy, G. \& Estades, A. 1991a: Contribution a l'étude du genre Leccinum S. F. Gray. — Docum. Mycol. 21(81):11-26.

Lannoy, G. \& Estades, A. 1991b: Contribution a l'étude du genre Leccinum S. F. Gray. - Docum. Mycol. 21(82):1-6.

Lannoy, G. \& Estades, A. 1993: Contribution a l'étude du genre Leccinum S. F. Gray. - Docum. Mycol. 23(89):63-71.

Lannoy, G. \& Estades, A. 1994: Contribution a l'étude du genre Leccinum S. F. Gray. 4) Essai de clé monographique du genre Leccinum S. F. Gray (pour l'Europe occidentale) - Docum. Mycol. 24(94):1-29.

Persson, O. 1992: Leccinum. In: Hansen, L. \& Knudsen, H. (eds), Nordic macromycetes 2:63-66. Nordsvamp, Copenhagen.

Smith, A. H. \& Thiers, H. D. 1971: The boletes of Michigan. -428 pp. Univ. Michigan Press, Ann Arbor, MI.

Watling, R. 1970: Boletaceae: Gomphidiaceae: Paxillaceae. British fungus flora 1. - $126 \mathrm{pp}$. Royal Bot. Garden, Edinburgh.

Received on 31 July 1995 